\title{
Optimazing operation and maintenance Telang II tidal reclamation scheme in relation to agricultural development
}

\author{
Megawaty $^{1^{*}}$, Robiyanto Hendro Susanto ${ }^{1}$, F. X. Suryadi ${ }^{2}$, Ngudiantoro $^{1}$ \\ ${ }^{1}$ Sriwijaya University, Palembang, Indonesia; ${ }^{*}$ Corresponding Author: egabambang@gmail.com \\ ${ }^{2}$ UNESCO-IHE Institute for Water Education, Delft, Netherlands
}

Received 2 November 2011; revised 18 December 2011; accepted 20 January 2012

\section{ABSTRACT}

The objective of this research is to study the hydraulic performance of the water management system of the Telang 2 tidal lowland reclamation scheme with respect to the operation and maintenance of the system. The hydraulic performance of the system should inline with the food crop water requirement and its cropping pattern. Based on the result of this research, a basic model will be set up in order to support a sustainable agricultural development in the area. The methodology of this research consists of 1 ) Analysing the hydraulic performance of the water management system for the existing condition as well as under the proposed scenarios; 2) socio-economical approach to the related farmers in relation to the operation and maintenance of the water management system; 3) Mathematical modelling of crop water requirement and an optimal water management system and its water management zoning system; 4) Cost benefit analysis related to operation and maintenance of the water management system, role sharing and cost sharing. In this study, computer softwares CROPWAT, DUFLOW dan ArcGIS have been used as supporting tools in the analysis and evaluation. CROPWAT model was used for calculating the crop water requirement based on the climatological condition and proposed cropping pattern (rice-maize and rice-rice) and its calendar. Based on the result of the CROPWAT model, DUFLOW model was used in order to evaluate the capacity and hydraulic performance of the open canal system. Finally based on the field water layer condition, water management zoning can be derived by using ArcGIS in relation to the crop water requirement and required water levels in the water manage- ment system. Based on this research, it can be concluded that the cropping pattern rice-rice or rice-maize are preferable and the co sharing is $50 \%$ by the Government and $50 \%$ by the farmers is the best option and this is also inline with the hydro-topographical condition of the related area.

Keywords: Optimalization; Water Management; Tidal Lowland Reclamation Scheme; Mathematical Modelling

\section{INTRODUCTION}

Indonesia has very high potential of lowlands, almost 4 million ha of the tidal lowlands in Indonesia have been reclaimed, partly by spontaneous settlers (2.5 million ha) and partly by the Central Government (1.5 million ha). These reclaimed areas generally have a good potential for agricultural development, with a rice crop in the wet season and a second rice crop, or a dry food crop in the dry season [1]. Especially on Java and Bali large areas are taken out of production, primarily due to urbanization. Tidal lowlands become more and more important and become the future for agricultural development potential in Indonesia because, mainly in Java there is continuously loss of fertile agricultural land for residential and industrial development. It is estimated that the rate of the loss of agricultural land is about 30,000 ha/year [2] (Soenarno, 1993).

In 2025 , it is projected that the population in Indonesia will become about 300 million inhabitants and because of that Indonesia will face a deficit of rice which is about 17.4 million ton per year [3] (Irianto, 2005).

One of the key factors to be success in the agriculture management and development in tidal lowlands is in the water management system and its control structures [4-8]. Based on this starting point, a research has been carried out an optimalization of water management system re- 
lated to the food crop (rice).

\section{PROBLEM DEFINITION, OBJECTIVES AND METHODOLOGY OF THE RESEARCH}

\subsection{Problem Definition}

So far the hydraulic performance of most of the tidal lowland schemes are still below the expectation. This performance is very much depends on the operation and maintenance of the water management systems. What will be an appropriate operation and maintenance in relation to the agricultural development in the related areas?

\subsection{Objectives of the Research}

The objectives of this research are as follows:

- To identify and to evaluate the hydraulic performance related to operation and maintenance of the tidal low- land reclamation scheme;

- To analyze and evaluate some non-technical aspects (socio, economy and culture) of the farmer society related to farming system and water management systems and also operation and maintenance in the related scheme;

- To set up and develop a water management system model which may be used to analyse and evaluate the hydraulic performance as the effect of operation and maintenance activities of the system in relation to its agricultural development.

\subsection{Methodology}

This research has been carried out in Primary 17, Secondary Block 5 South (P17-5S), Mulyasari village, Tanjung Lago Sub-District, Banyuasin District, and South Sumatra Province. The area covers 256 ha with 17 tertiary canals and with a distance of $200 \mathrm{~m}$ between two tertiary canals. The research location is shown in Figure 1. The

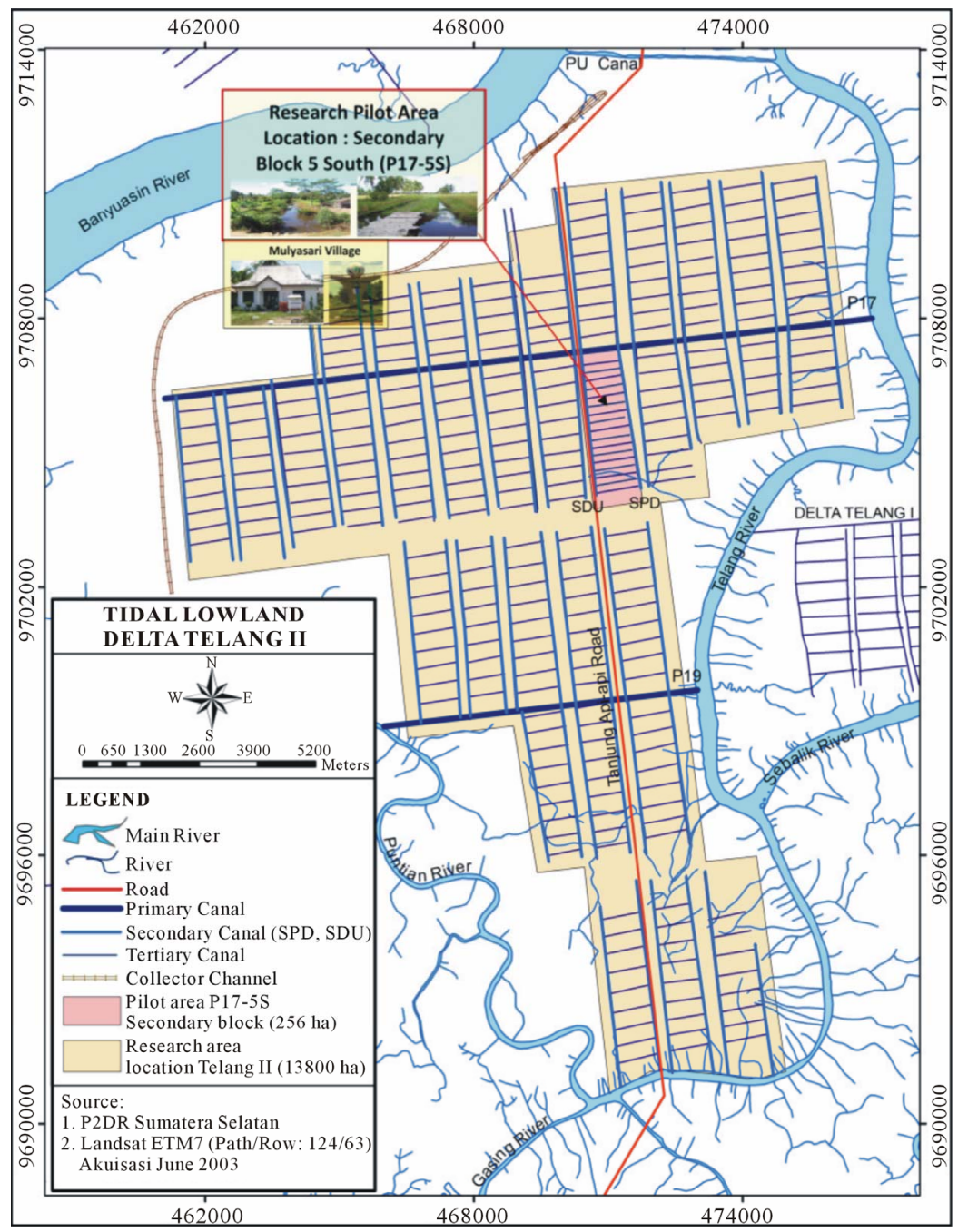

Figure 1. Location of research area. 
Delta Telang II covers an area of 13,800 ha.

\subsection{Method of Analysis}

The purpose of the analysis is to identify and to evaluate the potential and constraints the hydraulic performance of the tidal reclamation scheme in relation to operation and maintenance. The analysis consists of:

1) Land use image analysis. The intensity of the land use will show the operation and maintenance performance in the related scheme. Based on the collected satellite images, analysis has been done in order to study the land use pattern. The result of analysis was used as the basic for the field observation to the related water management system. The satellite image analysis can also be used to evaluate the potential of the area for agricultural development in the future.

2) Discussion with the farmer group prior to the scenario development. This activity is one of the primary data collection stages which consist of discussion, meeting, interview with the farmer society in the related area. The purpose of this activity is to get the direct information related to problems, constraints in the operation and maintenance of water management system, agriculture development, farming system, physical condition of the agriculture fields [9], agriculture product marketing, institutional aspects and the participative approach from the farmer side. All the information and data were used for deriving the scenarios related to operation and maintenance.

3) Analising the dominant factors related to operation and maintenance. The most dominant supporting factor consists of three factors [10], which are: a) lay-out of water management system and its operation and maintenance; b) agriculture and farming system; and c) institutional factor. These three factors will be analysed and evaluated and were used as reference for operation and maintenance model of water management system with the purpose to maximize the agricultural output.

4) Rainfall and climatological analysis. The data were collected from the station Sultan Mahmud Badaruddin II Airport of Palembang. Based on the 10 year daily data, the analysis was done by applying three methods, i.e. Normal, Gumbel and Log Pearson Type III and using the computer program Smada version 6.0.

5) Crop water requirement simulation by CROPWAT model. Six different scenarios will be studied:

Scenario 1: rice-fallow-fallow;

Scenario 2: rice-rice-fallow;

Scenario 3: rice-maize-fallow;

Scenario 4: maize-maize-fallow;

Scenario 5: rice-maize-maize;

Scenario 6: maize-maize-maize.

Next to the crop water requirement model simulation, canal water management system simulation will also be done by using DUFLOW model.

The basic data for DUFLOW model simulation composes of longitudinal and cross sectional data, the layout of the water management system included hydraulic control structures, boundary conditions (upstream and downstream) and design rainfall. As the result of the model, water levels and discharges in the water management system for different places can be obtained. The discharges and water level have to be compared with the result from CROPWAT model for the crop water requirement and the water levels have to be compared with the growing conditions of the crops. Related to the operation and maintenance strategies, the roughness coefficient of Chezy has to be judged as well (Table 1). Three different case were studied as shown in Table 2:

- Case 1: operation and maintenance is about $30 \%$;

- Case 2: operation and maintenance is about 50\%;

- Case 3: operation and maintenance is about $80 \%$.

6) Water management zoning (WMZ) analysis. Water management zoning (WMZ) is a unit of planning for land use which is a combination between physical characteristics of the area and proposed land use for the related area. Based on its WMZ, operation and maintenance of water management system (included hydraulic control structures) can be derived by considering cropping patter, cropping calendar of the area.

Water management zoning was done based on the area drainability and also its irrigability which are referred to

Table 1. Chezy roughness coefficient related to operation scenarios.

\begin{tabular}{ccc}
\hline Description of Channel & $\begin{array}{c}\text { Chezy } \\
\text { Coefficient }\end{array}$ & $\begin{array}{c}\text { OM } \\
\text { Scenario }\end{array}$ \\
\hline Many grove heights of flood waters & $7-12.5$ & $10 \%$ \\
$\quad \begin{array}{c}\text { Many weeds as high as water } \\
\text { Base of channel is clean with a little to } \\
\text { moderate grove on the cliff wall channel }\end{array}$ & $20-30$ & $50 \%$ \\
$\begin{array}{c}\text { Channel with a bit of short grassy weeds } \\
\text { Channel is clean and not a new channel, it } \\
\text { has been decaying }\end{array}$ & $30-45$ & $80 \%$ \\
\hline
\end{tabular}

Table 2. Cases and scenarios for operation and maintenance.

\begin{tabular}{cccc}
\hline & & \multicolumn{2}{c}{ Chezy Coefficient $\left(\mathrm{m}^{1 / 2} / \mathrm{s}\right)$} \\
\cline { 3 - 4 } Cases & Scenarios & $\begin{array}{c}\text { Dry } \\
\text { Season }\end{array}$ & $\begin{array}{c}\text { Wet } \\
\text { Season }\end{array}$ \\
\hline $\begin{array}{c}\text { OM 30\% } \\
(\text { Less })\end{array}$ & Without building water \\
gates & 15 & 15 \\
$\begin{array}{c}\text { OM 50\% } \\
\text { (Medium) }\end{array}$ & $\begin{array}{c}\text { With water gates in } \\
\text { secondary canal }\end{array}$ & 20 & 20 \\
$\begin{array}{c}\text { OM 80\% } \\
\text { (Good) }\end{array}$ & $\begin{array}{c}\text { With water gates in } \\
\text { secondary and tertiary canal }\end{array}$ & 40 & 40 \\
\hline
\end{tabular}


the hydro-topographical conditions of the area and its land suitability for food crop development [11].

7) Physical conditions of the research area and other supporting infrastructure. Originally, the water management system in this area based on the one way flow system where during high tides, water will enter the system through SPD secondary canals and during low tides, water from the system will be drained through SDU secondary canals [12]. The distance between two primary canals is $8000 \mathrm{~m}$ and between two secondary canals (SPD and SDU) is $1150 \mathrm{~m}$ (see Figure 1). In the present conditions, all SPD and SDU secondary canals are used as supply and drainage canals as well [12].

Most of the tertiary canals are not modified yet, only some of them in Secondary Block 5 South were modfied at this moment. One secondary block covers an area of 256 ha and consists of 9 tertiary canals (see Figure 1). At the beginning, all SPD and SDU canals have an open connection with the primary canal [13]. In 2009, 5 gates were constructed in secondary canal SDU 7 North, SDU 7 South, SDU 8 North, SDU 8 South and SDU 9 North.

In general, the physical condition of the water management system P17-5S is under unproper operation and maintenance. In most of the canals, weeds are growing quite thick. Due to the sedimentation problem, most of the tertiary canals are shallow where the deposition are estimated about $0.8-1.0 \mathrm{~m}$. Crop is only once a year where rice was cultivated and the yield was about $3-4$ ton GKP/ha (between year 2009-2010).

There is a collector drain was constructed with $3.5 \mathrm{~km}$ long and it was re-shaped in November-December 2009. This collector drain is connected to tertiary canals and finally to the secondary canal SDU.

Due to the lack of the financial support from the Government, farmers almost did not clean the tertiary canals. Farmers only used pestiside to control the weeds in the tertiary canals. Only some of the tertiary canals were added and the distance between two tertiary canals becomes $200 \mathrm{~m}$ and 5 tertiary canals were connected to the secondary canal SPD, i.e. tertiary 4, 5, 9, 13 and tertiary 16 and the connection is done by constructing a culvert (done by farmers).

On some parts of the area where they belong to hydrotopography category C (P17-8 North Bangunsari Village), farmers already grow oil palm instead of rice. This change is logic due to the high field elevation there is no water can be expected flow to the field and also due to the condition of the canals (poor maintenance). As the conclusion operation and maintenance at micro as well as macro level is not done sufficiently. The physical conditions of the water management system and its hydraulic control structures are showm in Figure 2.

8) Socio-economy and culture of the farmer society. Agriculture is the main activity of the farmers in this area.
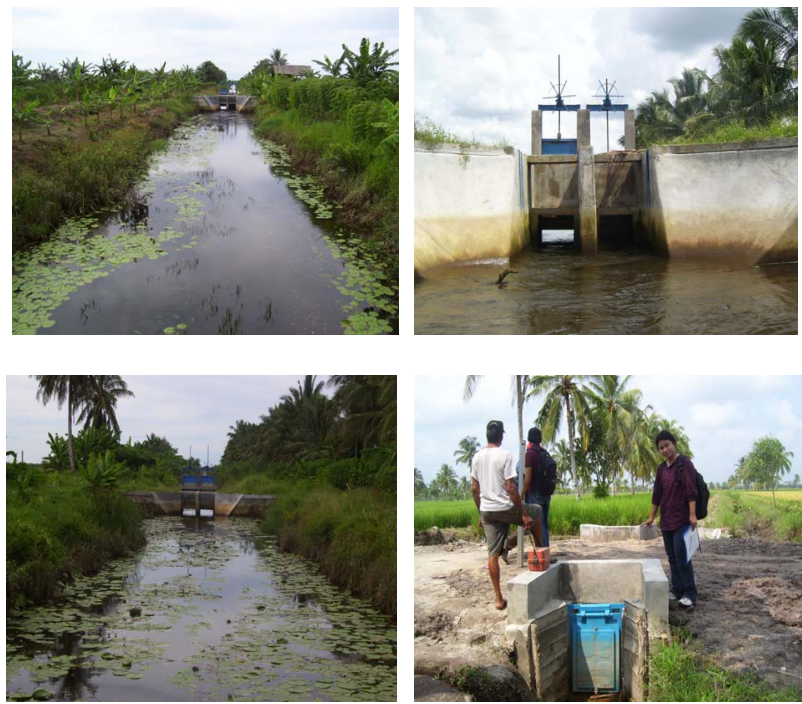

Figure 2. Physical conditions of the canal system in P17 Telang II.

Next to that, in this area there is a market where farmers can sale their products and there is also a cooperation where they can borrow some money to support their farming activities [14].

Besides cooperation, there are also persons for Agriculture Service at field, Village Society Unit and Water Users Association (WUA). WUA was passive and did not function optimally yet and for that reason support from government institutions are still needed.

9) Analysis of farming system. Some of farmers have tried to grom rice-rice-fallow or rice-maize-fallow, but the the second crop produced a quite low yield. For agriculture field (Mulyasari Village) which belongs to category $\mathrm{C}$, water availability during the second crop is still a problem. But for agriculture fields which belong to category $\mathrm{A} / \mathrm{B}$ there was problem with drainage [5-7]. During high tides and rainy season, excess water from the agriculture field can not be drained to the main system [6]. For this purpose, hydraulic control structure will be needed (at secondary or tertiary level) [5] dan [15]. The field conditions are shown in Figure 3.

Besides hydraulic control structure and its operation, the maintenance system has to be done properly as well [16].

To analyse crop water requirement at field level, several data will be needed and have to be collected, among others: cropping pattern and related farming system [17]. It was found that cropping pattern was ricefallow-fallow.

\section{OPERATION AND MAINTENANCE COST, ROLE AND COST SHARING}

As the final stage of the analysis, role sharing, res- 

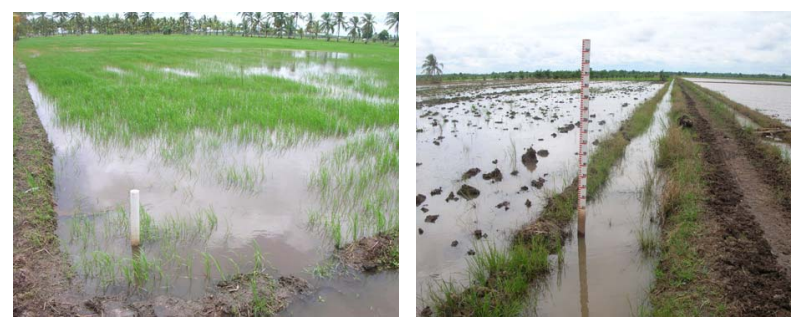

Figure 3. Inundation of the agriculture field.

ponsibility and cost sharing in the operation and mainnance activities of the related stakeholders will be evaated. The stakeholders consist of Central Government component, Provincial and District Institutions as well as farmers $[12,15,16]$.

The operation and maintenance cost will be based on the actual requirement for operation and maintenance and for that purpose, three different scenarios have been proposed:

Scenario A: all the operation and maintenance activities for primary, secondary and tertiary canals will be financed by the Central Government (APBN).

Scenario B: Central Government will finance only operation and maintenance of primary and secondary canals. Next to that all the routine operation and maintenance of the tertiary canals will be financed by the Water Users Association.

Scenario C: The Government will finance only all the operation and maintenance of the primary canals. For secondary canals, the Government will provide all the required materials related to operation and maintenance and the execution will be done by the Water Users Association. Operation and maintenance of tertiary canals will also be done by the Water Users Association.

\section{HYDRO-TOPOGRAPHY}

The hydro topographical condition is defined as the elevation of the fields relative to actual high canal water levels at the nearest drainage or intake point, and usually expressed in the number of tidal irrigations which can be applied. Hydro-topography is classified based on the following (after Euroconsult, 1993) [11,12,18] as shown in Figure 4.
Category A: tidal irrigated areas, in both wet and dry season.

Category B: tidal irrigated areas, only in the wet season.

Category $C$ : areas just above $(\leq 0.50 \mathrm{~m})$ the average high water level in wet season.

Category D: water levels independent from tidal influence.

The topographical condition of the research area in Telang II is flat and the elevation is between $1.5 \mathrm{~m}$ to 2.0 $\mathrm{m}+\mathrm{MSL}$. Based on the analysis, the hydro-topographical of the area belongs to category $\mathrm{B}$ and $\mathrm{C}$.

\section{MATHEMATICAL MODELLING}

In this research, three different models namely DUFLOW, CROPWAT and ArcGIS were used.

\subsection{DUFLOW}

This is an unsteady model which can be used for open water management systems included different hydraulic control structures such as weir, culvert and pumping station.

Basic equations. St Venant equation which composed of:

- Continuity equation:

$$
B \frac{\partial \eta}{\partial t}+\frac{\partial Q}{\partial x}=q
$$

where $t$ is time (s), $B$ is surface width of the wetted crosssection $(\mathrm{m}), Q$ is flow discharge $\left(\mathrm{m}^{3} / \mathrm{s}\right), q$ is lateral flow $\left(\mathrm{m}^{2} / \mathrm{s}\right)$, and $\eta$ is water level above the reference level (m).

- Momentum equation:

$$
\frac{\partial Q}{\partial t}+\frac{\partial}{\partial x}\left(\beta \frac{Q^{2}}{A}\right)+g A \frac{\partial \eta}{\partial x}+g \frac{Q|Q|}{A C^{2} R}=0 .
$$

where $A$ is wetted cross-section $\left(\mathrm{m}^{2}\right), \mathrm{g}$ is acceleration due to gravity $\left(\mathrm{m} / \mathrm{s}^{2}\right), R$ is hydraulic radius $(\mathrm{m}), C$ is Chezy coefficient $\left(\mathrm{m}^{1 / 2} / \mathrm{s}\right), \quad \beta$ is Boussinesq coefficient.

\subsection{CROPWAT}

CROPWAT software was used to calculate the crop

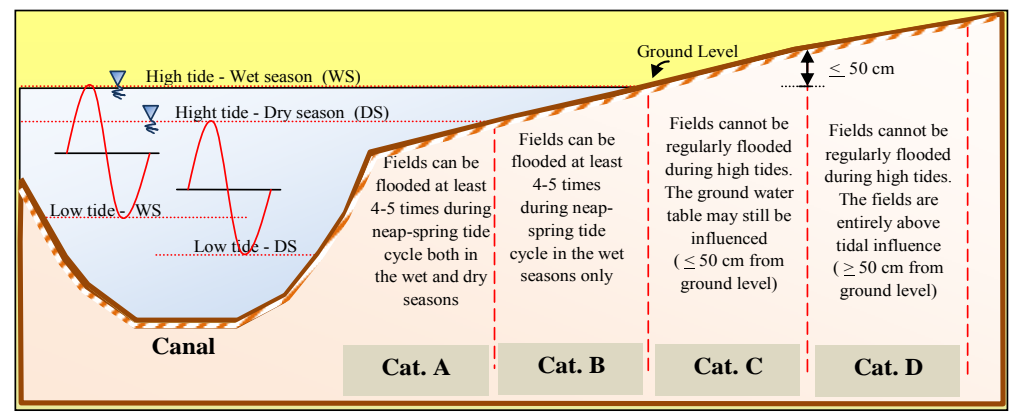

Figure 4. Hydro-topography. 
water requirement at the field level based on the selected cropping pattern and cropping calendar.

\subsection{ArcGIS Model}

Geographical information system is a combination of hardware and software which can be used to model, analyze and evaluate spatial data which are related to water management zoning and based on its hydro-topographical conditions.

\section{ANALYSIS AND EVALUATION}

\subsection{Inundation Pattern Analysis}

By overlaying the simulated water levels land topographical conditions of the area, the inundation patterns map for the macro level of the area can be obtained.

\subsubsection{Case 1 (OM 30\%)}

This case is based on the model simulation with the condition of OM $30 \%$ where the physical conditions of the canal system is related to the actual conditions without hydraulic control structure. The model simulations have been done both for the dry as well as for the rainy season. The result of inundation patterns for each season are presented in Figure 5.

It is clear that in the dry season, only a small part of the study area (472 ha) will be flooded with the inundation depth of $\leq 0.34 \mathrm{~m}$ (Figure 5(a)) and water levels in the canals will varies between 0.0 to $0.50 \mathrm{~m}$ below the land surface (122,090 ha).

Meanwhile, in rainy season in combination with high tides (Figure 5(b)) is shown that most of the area will be inundated. Only small part of the study area will not inundated.

\subsubsection{Case 2 (OM 50\%)}

Case 2 with OM 50\%, where in the secondary canals are completed with hydraulic control structures and in tertiary canals without hydraulic control structure and the result is presented in Figure 6.

The water levels in the canals will vary between 0.0 to $0.50 \mathrm{~m}$ below the land surface. The water level in some parts of the area (1690 ha) will be lower than $0.50 \mathrm{~m}$ below the land surface. Only 436 ha of area which will be inundated with the inundation depth of $\leq 0.335 \mathrm{~m}$ (Figure 6(a)). Meanwhile, from Figure 6(b) is shown

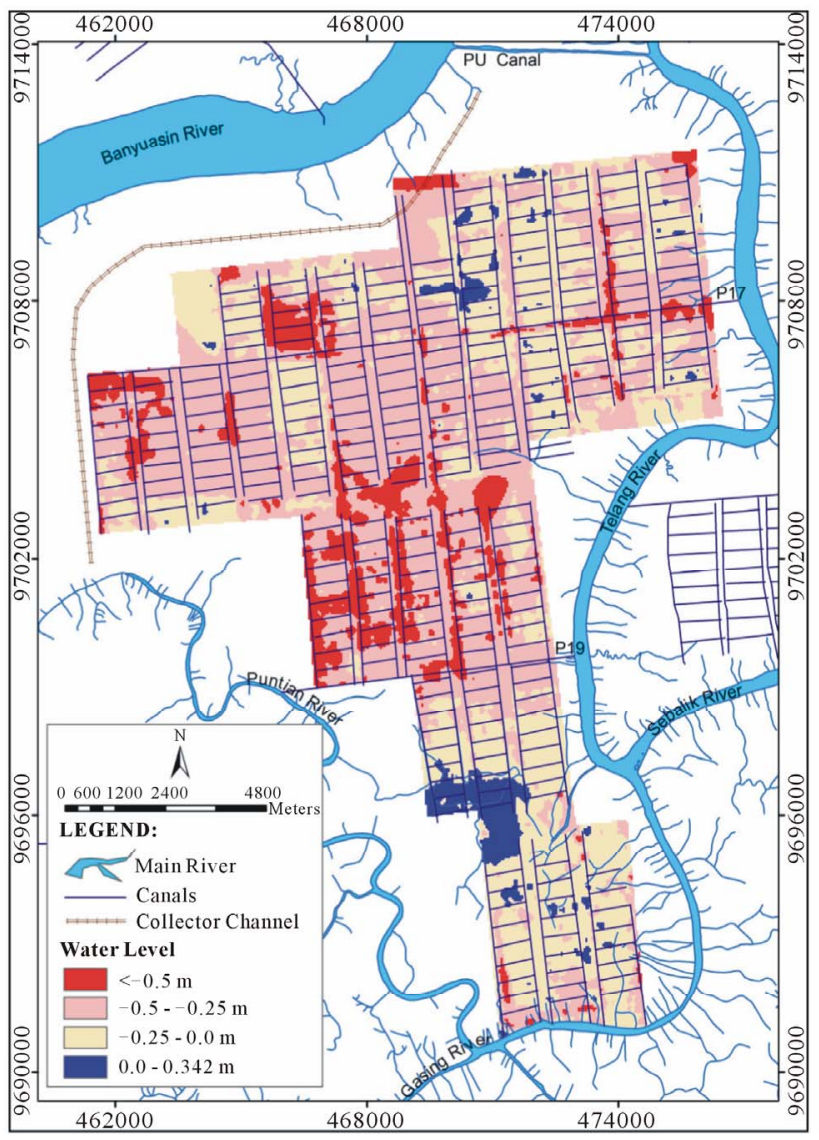

(a)

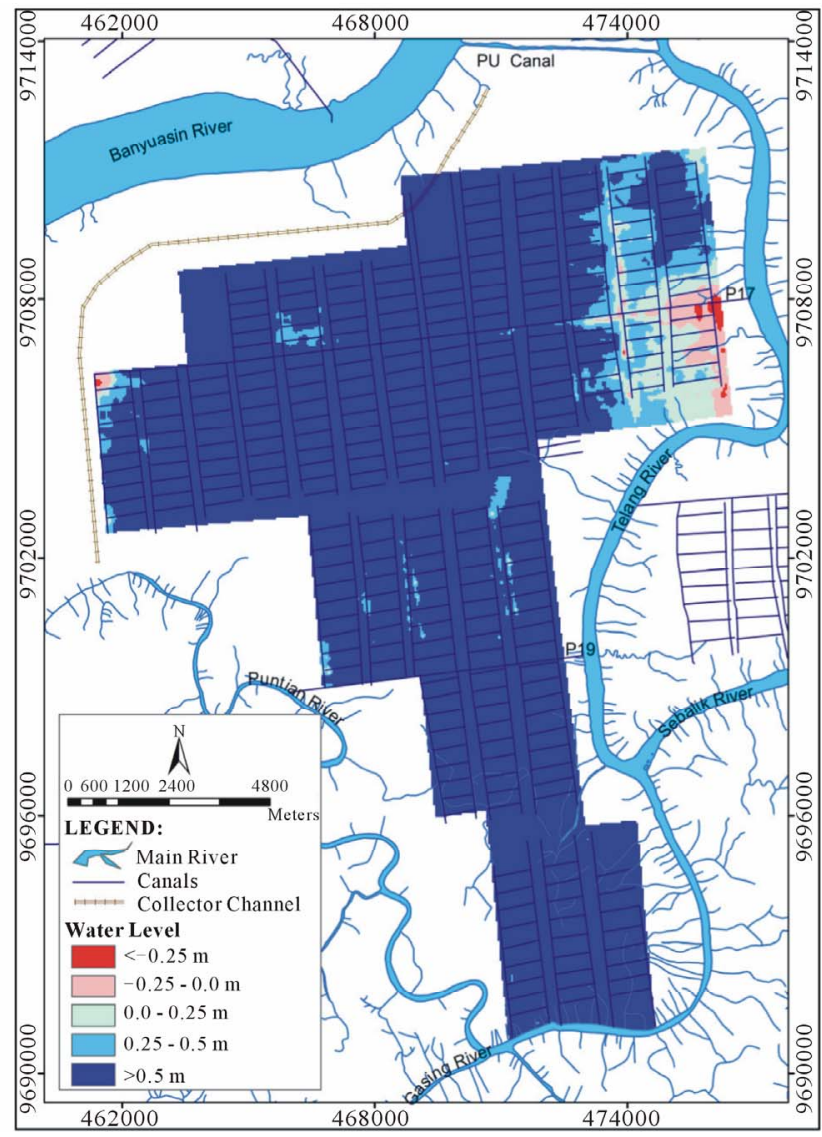

(b)

Figure 5. Inundation map in dry season (a) and rainy season (b), Case 1. 


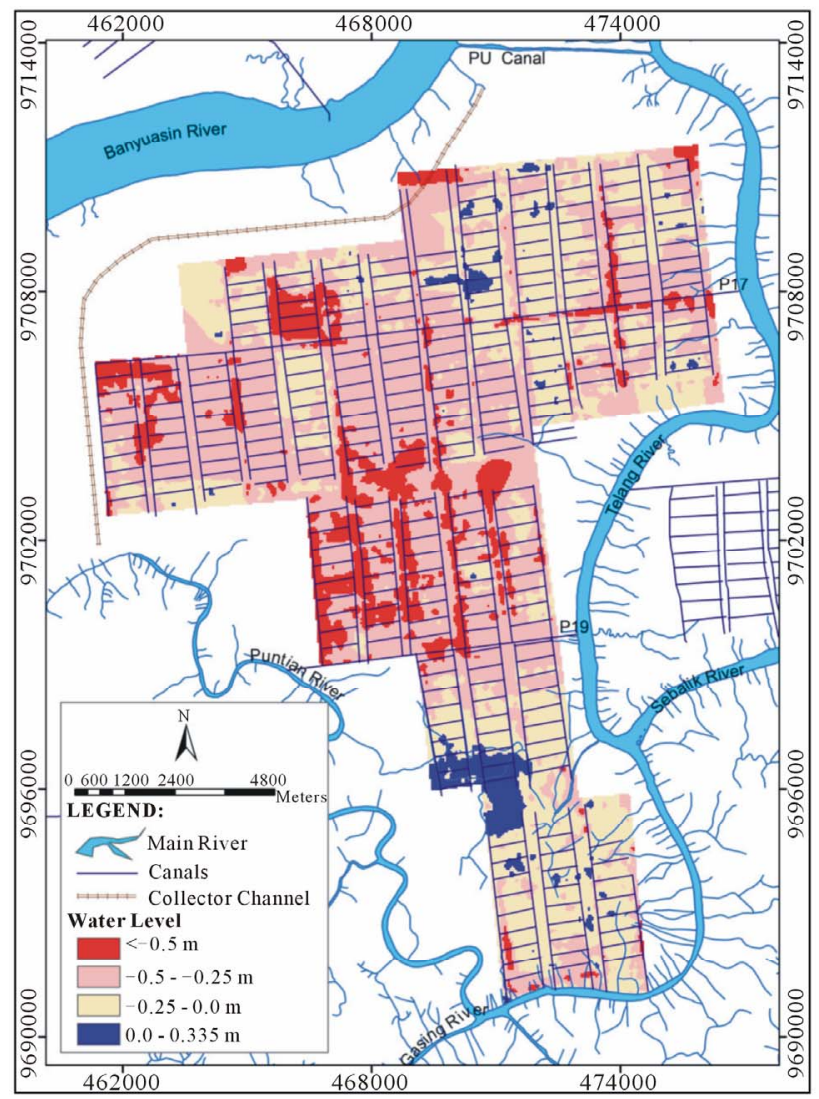

(a)

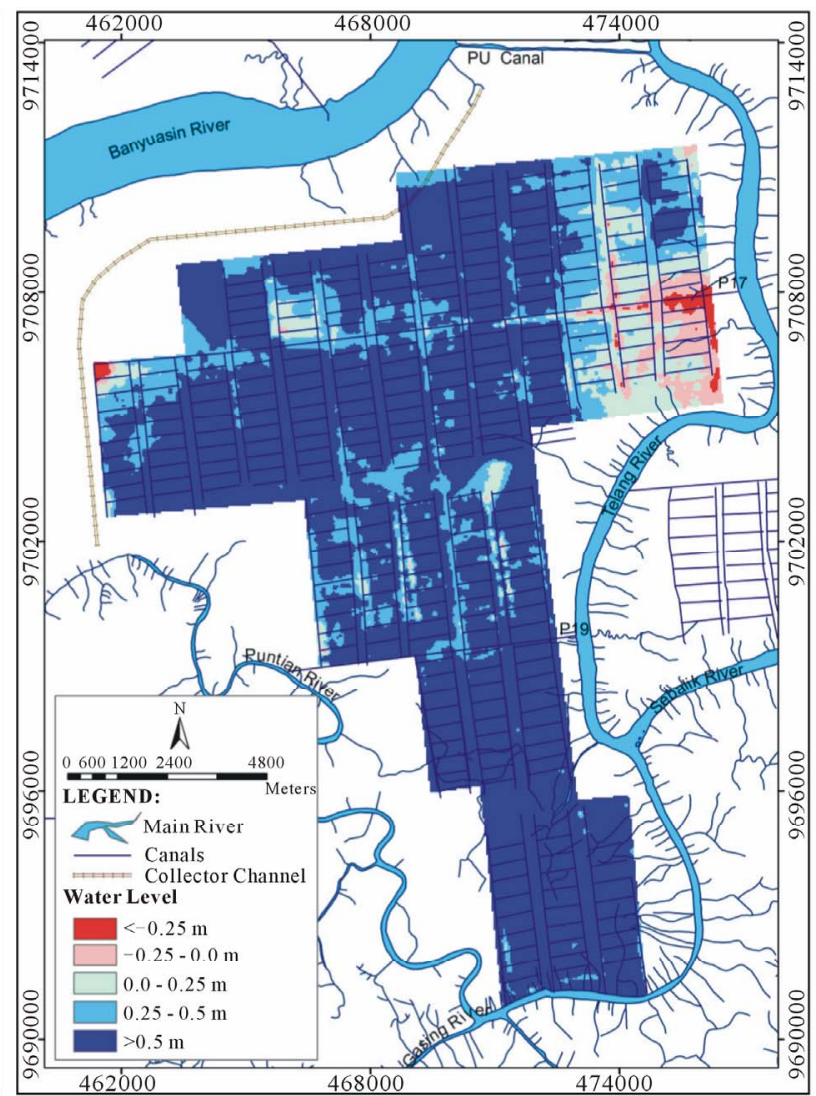

(b)

Figure 6. Inundation map in dry season (a) and rainy season (b) Case 2.

that in general most of the area will be inundated during the rainy season in combination with high tides. By comparing Case 1 (OM 30\%) with Case 2 (OM 50\%) it is clear the effect of the hydraulic control structure in the secondary canals will be significant to the water levels in the secondary canals but not in the inundated pattern on field level (only slightly reduced).

\subsubsection{Case 3 (OM 80\%)}

In Case 3, OM $80 \%$ is divided into two scenarios, that is: 1) channel with complete water gates at each tertiary canal, but without gates on the secondary canals, and 2) channel complete with water gates at each secondary and tertiary canals.

1) Hydraulic control structures (gates) in all the secondary canals and culverts in tertiary canals

The result shows in Figure 7(a) that for the dry season, there is almost no inundation. Again, only 432 ha of area which will be inundated with the depth of $\leq 0.35 \mathrm{~m}$. In general, water levels in the canal will vary between 0.0 to $0.50 \mathrm{~m}$ below the land surface $(11,944 \mathrm{ha})$ and in some parts, the water levels will be lower than $0.50 \mathrm{~m}$ below the land surface (1876 ha). Meanwhile, from Figure 7(b) for the rainy season, the results are quite different than the previous scenario. During the rainy season in combi- nation with high tides, much smaller area will be inundated. Water levels are well controlled by the hydraulic control structures in the secondary canals and also culverts in tertiary canals.

2) Hydraulic control structures (gates) in the secondary as well as in the tertiary canals

For the dry season condition (Figure 8(a)), it is comparable with the previous scenarios. In this scenario, only 447 ha of the areas which will be inundated and the depth is $\leq 0.35 \mathrm{~m}$. By comparing with Case 3 Scenario 1 above, it is clear the effect of the hydraulic control structures (gates) in the secondary and tertiary canals to the inundation condition of the area. See Figure 8(b) where the inundated area during rainy season is significantly larger than the previous scenario.

In this scenario, 8106 ha will be inundated, while the area without inundation will be about 6145 ha. It is almost inversely condition to the inundation condition in Case 3 Scenario 1.

By comparing these two scenarios, it can be concluded that the an optimal water management for this area can be achieved by doing a proper operation of hydraulic control structures in the secondary as well as in the tertiary canals. Construction of the secondary gate (SPD and $\mathrm{SDU}$ ) is recommended because its existence is important 


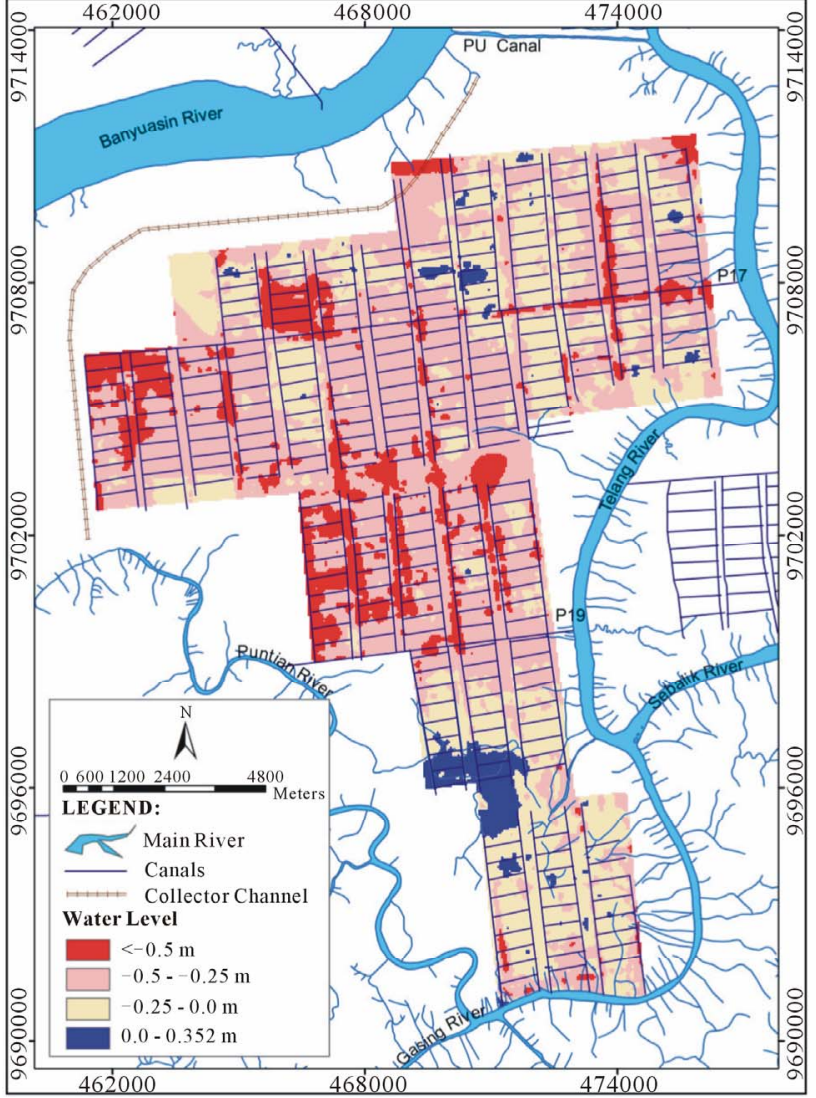

(a)

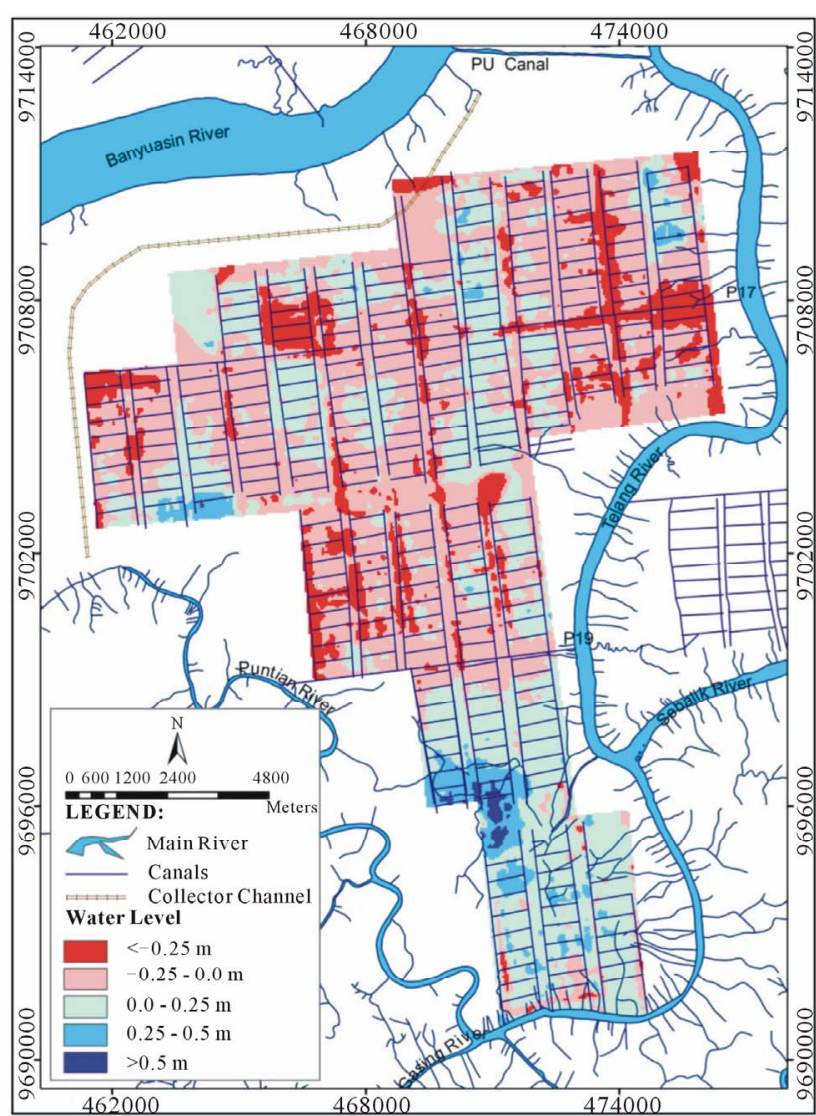

(b)

Figure 7. Inundation map in dry season (a) and rainy season (b) Case 3.1, hydraulic control structure (gate) in each tertiary canal.

to control and hold water in order to prevent too rapid loss of water [15] (LWMTL, 2006).

\subsection{Crop Water Requirement Analysis by CROPWAT Model and DUFLOW Model in Telang II}

From the results of calculations by CROPWAT and $D U F L O W$ models, then for the following four cropping pattern:

- rice-fallow-fallow;

- rice-rice-fallow;

- rice-maize-fallow;

- rice-maize-maize.

They are all possible for the rainy season in most of the Telang II area with hydro-topography category B where the water availability is sufficient for crop water requirements. But water levels have to be controlled by the gates with a proper operation in the secondary and tertiary canals.

Especially for cropping pattern maize-maize and maizemaize-maize, they could be possible to be cultivated in most area in Delta Telang II. However, based on field conditions, rice crop can only be possible for the first crop season (rainy season).
However, for cropping pattern rice-rice-fallow, ricemaize-fallow and rice-maize-maize, they would be difficult to achieve without improving the physical condition of the water management system and its hydraulic control structures $[4,5,6,15]$.

Based on the results of CROPWAT and DUFLOW models, the relationship between the hydro-topography conditions, drainage requirements and the supplementary water requirement can be described. This relationship is presented in Figure 9.

From Figure 9, it is clear that required supplementary water supply is small in comparison with the drainage requirement of the system. This is of course in accordance with the physical condition of the field related to the hydro-topographical condition of the area.

By using this correlation as shown in Figure 9 can be used for initial planning phase of water management systems and the related operation and maintenance strategies in accordance with the hydro-topographical conditions of the area.

\subsubsection{Water Management Zoning Model}

By using the result of CROPWAT model simulations, the capacity of the water management system has been evaluated by using DUFLOW model. In fact, the dis- 


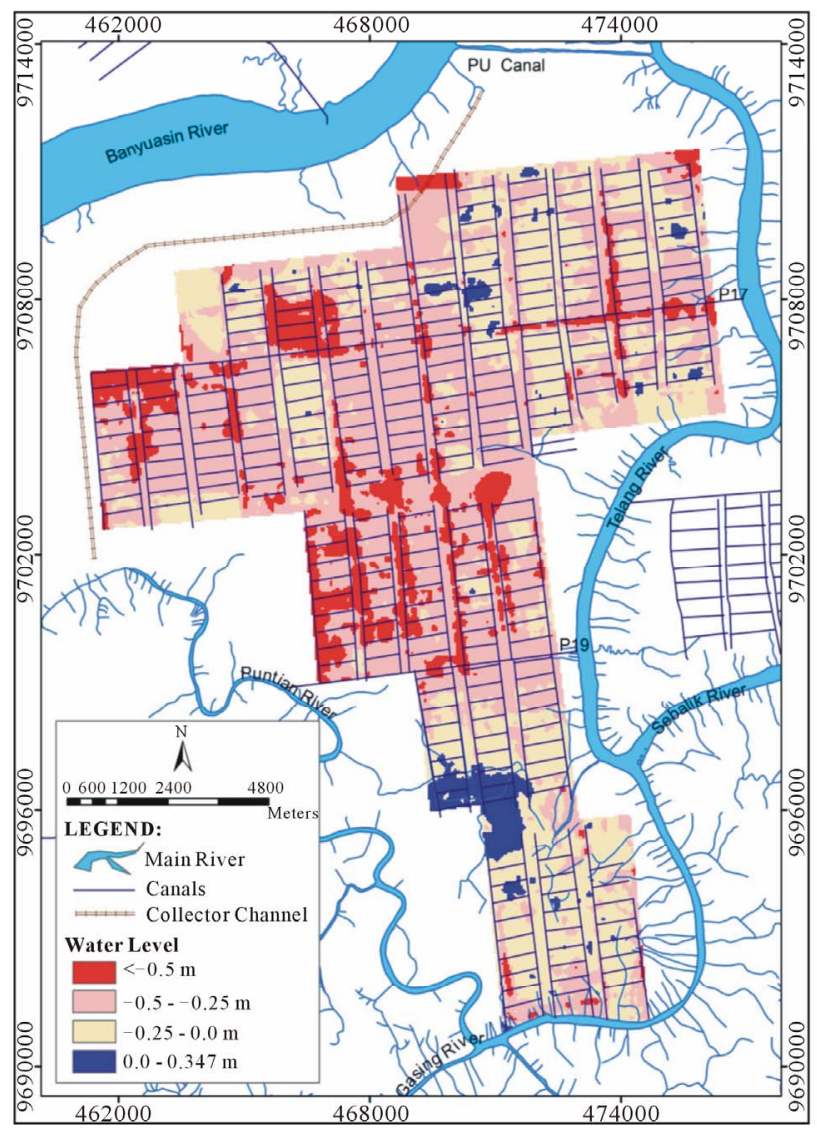

(a)

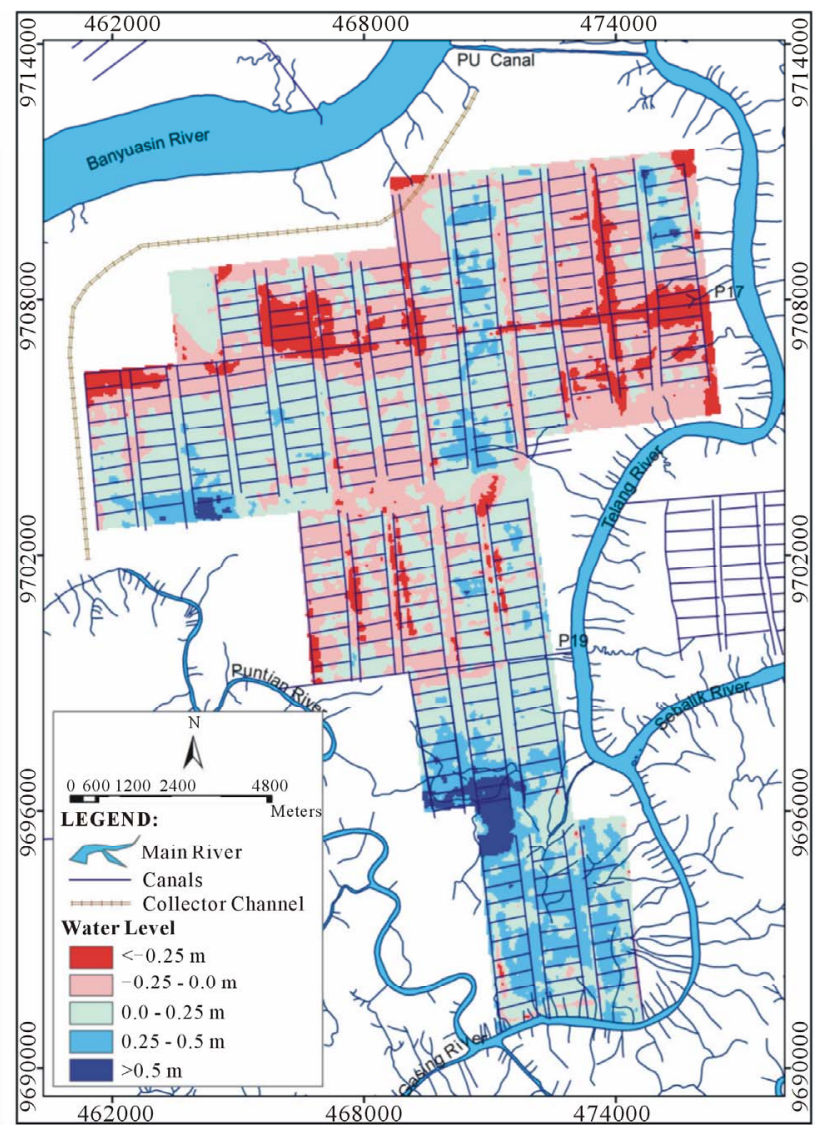

(b)

Figure 8. Inundation map in dry season (a) and rainy season (b) Case 3.2, hydraulic control structure in secondary and tertiary canals.

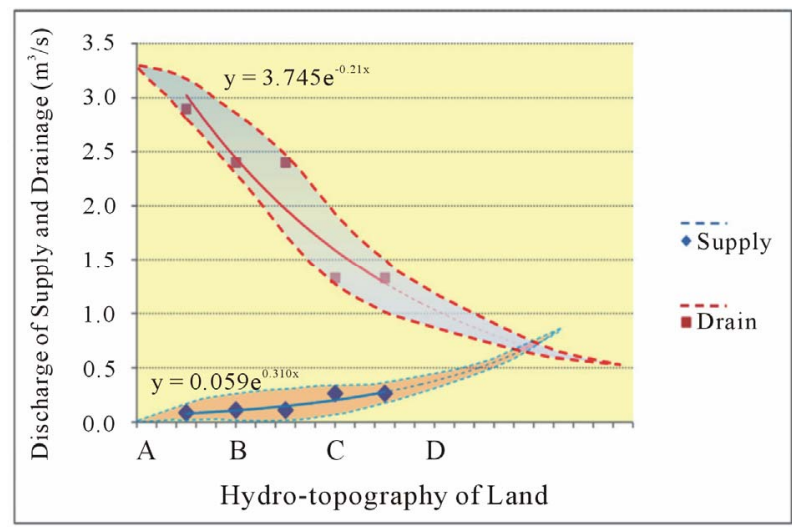

Figure 9. Correlation between supply and drainage.

charge capacity of the water management system in this Telang II area is sufficient to drain the excess water during rainy season. By considering the hydro-topographical conditions of the area and the result of CROPWAT and DUFLOW model, proposed water management zoning for Telang II area has been derived as shown in Figure 10.

This water management zoning as shown in Figure 10 can be used to make a plan related to the cropping pat- tern, type of hydraulic control structure and operation and maintenance which will be needed in the water management system of the related block or area. In this case the water management zoning is defined per secondary block.

Operation and maintenance procedure for each secondary block can be derived and for practical purposes, it should be as simple as possible.

\subsubsection{Analysis of the Realistic Requirements Numbers of Operations and Maintenance}

Based on the calculation of the actual cost of Operation and Maintenance with the actual needs (AKNOP), the correlation between the government and the farmers in role and cost sharing related to the implementation of operation and maintenance activities in a secondary block can be obtained as shown in Figure 11.

From Figure 11 it is clear that the roles sharing of farmers in terms of routine maintenance at the tertiary canal would be optimal if the contribution from the farmers is $50 \%$ and the government is also $50 \%$. It can be seen that the optimal correlation (crossing point) between the government and the farmers will be achieved if cost 


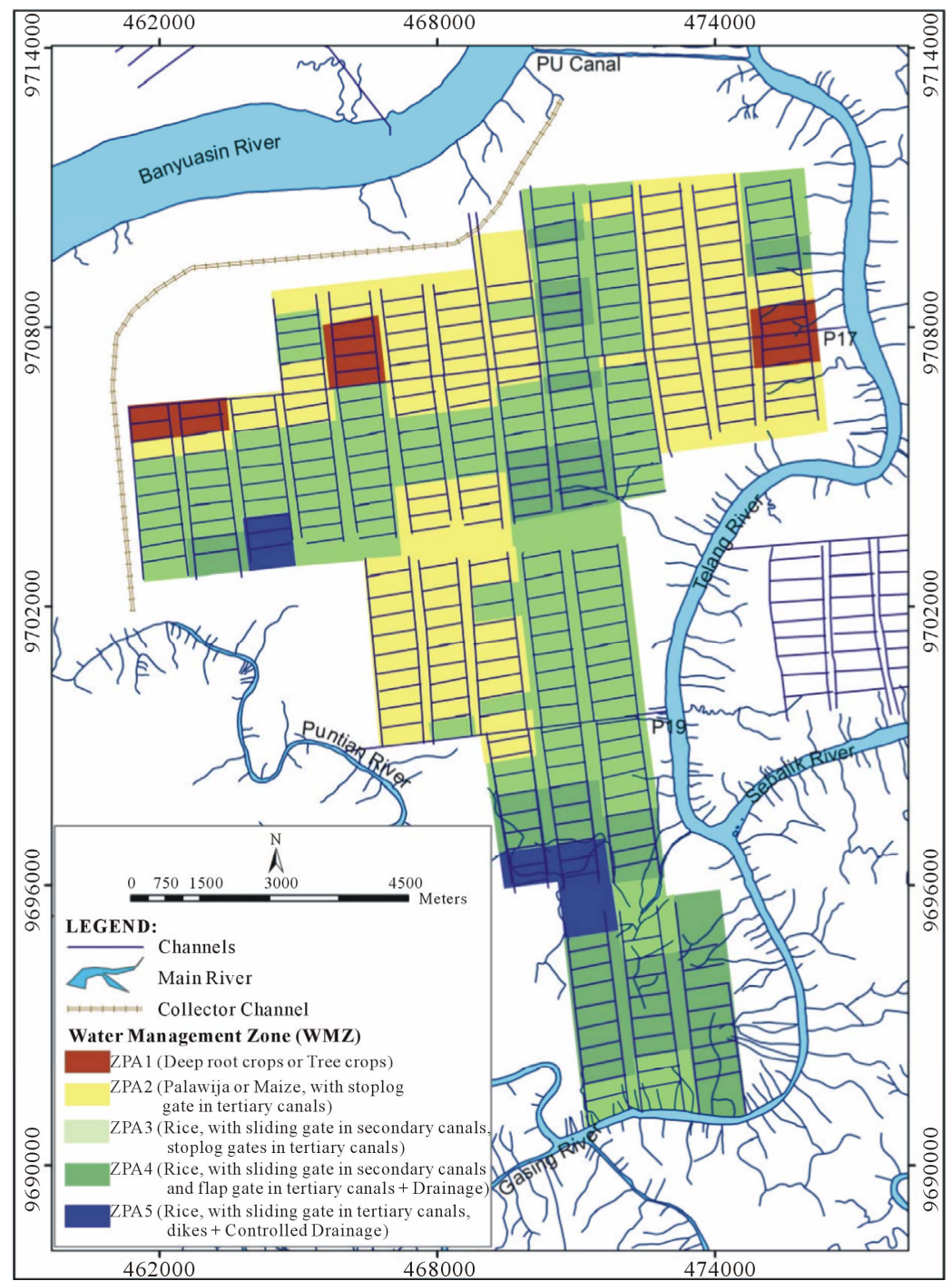

Figure 10. Water management zoning.

routine OM incurred at IDR 33, 109, 500.

\section{CONCLUSIONS AND SUGGESTING}

\subsection{Conclusions}

- From the results of the modeling simulation by DUFLOW and the related inundation pattern, it can be concluded that the optimal water management for the tidal lowland in Delta Telang II will be through the operation of hydraulic control structures both in the secondary and tertiary canals where the level of operation and maintenance is assumed $80 \%$. This means that the water management should not only be done in the macro or micro level, but will be more optimal if the water management can be done in a balance way both at the macro and micro level where they will influence each other.

- In general it can be concluded that for hydro-topo- graphy B and C category areas drainage is more important than water supply. Therefore, to it is necessary to install hydraulic control structure in relation to the crop water requirement at the field level.

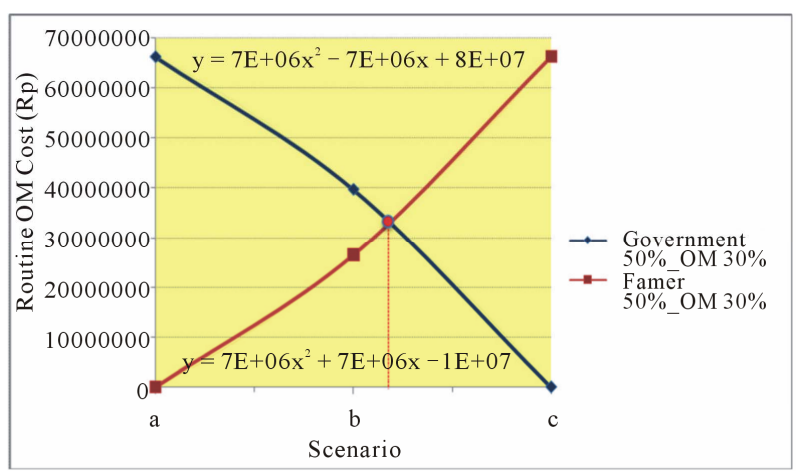

Figure 11. Relationship between role and cost sharing between government and farmers in operation and maintenance. 
- For practical consideration, water management zones unit should be made for each secondary block where uniform cropping pattern, operation and maintenance of water management system can be planned properly. Only for certain spots where the physical conditions (topography) which are somewhat extreme, the water management zoning can be defined for each tertiary block.

- By combining the water management zoning with the design criteria for tidal lowland, the suitable cropping patterns, operation and maintenance for the related tidal lowland reclamation unit can be derived.

- Roles sharing of farmers in terms of routine maintenance for the tertiary canals would be optimal if farmers will do $50 \%$ and government also $50 \%$ in term of involvement.

- Cropping pattern of rice-fallow-rice or rice with two times planted system will give the most beneficial output for the farmers. While cropping patterns of rice-maize-fallow and rice-maize-maize can only provide benefit about $50 \%$ in comparison with the first option.

\subsection{Suggesting}

- To be able to improve the performance of water management system in Delta Telang II, the government is proposed to construct infrastructures that needed such as hydraulic control structure in every tertiary and secondary canal.

- In case additional tertiary canals have to be constructed then the government should support and execute it in consultation with the farmer groups.

- For tertiary canals, farmers have to do the maintenance based on the participatory approach through the balanced role and cost sharing and guidance can be expected from the related government institutions.

\section{ACKNOWLEDGEMENTS}

The authors would like to thank the Public Works Services of South Sumatra Province for allowing carrying out the research and all the related data. Special appreciation is directed to Sriwijaya University and UNESCO-IHE for all the academic supports during this research period.

\section{REFERENCES}

[1] Suprianto, H, Irianto, S.G., Susanto, R.H, Suryadi, F.X. and Schultz, B. (2006) Potentials and constraints of water management measures for tidal lowlands in south sumatera. Case study in a pilot area in Telang I. 9th InterRegional Conference on Environment-Water, Delft, 17-19 May 2006.

[2] Soenarno (1993) Irrigation management transfer in Indo- nesia. Paper: Directorate general of water resources development. Ministry of Public Works, Nairobi, (in Indonesian).

[3] Irianto, S.G. (2005) Policy and water management in the valley swamp land development (in Indonesian). http://balittra.litbang.deptan.go.id/prosiding06/Utama-2.p df

[4] Suprianto, H., Irianto, S.G., Susanto, R.H., Schultz, B., Suryadi, F.X. and Eelaart, A.V.D. (2009) Land and water management of tidal lowlands: Experiences in Telang and Saleh, South Sumatra. Irrigation and Drainage Journal, 59, 317-335.

[5] Imanudin, M.S. (2010) Strategy of ground water surface control operating for tidal lowlands agricultural of South Sumatra Indonesia. Ph.D. Thesis, Sriwijaya University, Palembang, (in Indonesian).

[6] Imanudin, M.S. and Susanto, R.H. (2003) The applicable review of water management in tidal lowlands reclamation regional of delta Telang I of South Sumatra in support of $200 \%$ cropping index. Proceedings of Seminar and National Workshop on Sustainable Agricultural Development in an Era of Regional Autonomy and Globalization, Tridinanti University and Sriwijaya University, Palembang, (in Indonesian).

[7] Imanudin, M.S., Susanto, R.H., Diha, M.A., Guntur, M.A., Bakri, Hermawan, A., Priatna, S.J., Ibrahim, Halimi, E. and Suwignyo, A. (2002) Technical guidance repairment of micro water system on land farm of upang delta tidal lowland. Report of Community Services, Sriwijaya University, Palembang, (in Indonesian).

[8] Suriadikarta, D.A., Supriadi, H., Malian, H., Desmiyati, Z., Suwarno, M., Januwatu and Anang, H.K. (1998) Readiness of technology and development constraints of farm in swamp area. Proceedings of National Seminar on the Annual Meeting of Komda HITI, Malang, 16-17 December 1998, (in Indonesian).

[9] Directorate of Land Management. (2009) Technical guidelines for development of integrated farm conservation land (PUKLT). Directorate General of Land and Water Management, Ministry of Agriculture, Jakarta, (in Indonesian).

[10] Harsono, E. (2008) Flow system relations in water management system with land and water quality in support of land productivity in tidal lowlands. Ph.D. Thesis, Tarumanegara University, Jakarta, (in Indonesian).

[11] Suryadi, F.X. (1996) Soil and water management strategies for tidal lowlands in Indonesia. Ph.D. Thesis, Delft University of Technology-IHE, Delft.

[12] Satker SIRASS, Department of Public Works. (2005) Final report of study of stabilization operations and maintenance of wetlands in South Sumatra province. Development and Planning Activities of temporary work unit of mainstay irrigation and swamp of South Sumatra, Jakarta, (in Indonesian).

[13] Balai Wilayah Sungai Sumatera VII. (2009) Design review for tidal lowland scheme delta Telang II 5100 ha, Banyuasin Regency, Final Report, South Sumatra Province, Jakarta (in Indonesian).

[14] Ministry of Manpower and Transmigration. (2010) Inte- 
grated Independent City: Areal Profile KTM Telang, (in Indonesian)

http://ktm.depnakertrans.go.id $/$ ?show $=\mathrm{ktm} \&$ category $\mathrm{id}=$ $19 \& \mathrm{sub}=$ profile.

[15] LWMTL. (2006) Land and Water management of tidal lowlands program-LWMTL in Banyuasin Regency of South Sumatra Province, June 2004-August 2006 (in Indonesian).

[16] Report of the Joint Indonesian. (2004) Technical Guidelines on Tidal Lowland Development Volume III: Opera- tion and Maintenance. Regional Teaching Seminar on Guidelines on Tidal Lowlands, Jakarta, 6-7 October 2004.

[17] Smith, M. (1991) CROPWAT: Manual and guidelines. FAO, Rome.

[18] Euroconsult, Biec and Trans Intra Asia (1993) Programme and set up of water management trials in Telang and Saleh agricultural development project, drainage development component, South Sumatra Province. Technical Note 7-9, Ministry of Public Works, Jakarta. 